\title{
Uji daya hambat ekstrak daun lidah mertua (Sansevieriae trifasciata folium) terhadap pertumbuhan bakteri Escherichia coli dan Streptococcus sp
}

\author{
${ }^{1}$ Brily Lombogia \\ ${ }^{2}$ Fona Budiarso \\ ${ }^{2}$ Widdhi Bodhi \\ ${ }^{1}$ Kandidat Skripsi Fakultas Kedokteran Universitas Sam Ratulangi Manado \\ ${ }^{2}$ Bagian Kimia Fakultas Kedokteran Universitas Sam Ratulangi Manado \\ Email: brily_jo@yahoo.com
}

\begin{abstract}
Mother in law's tongue plant has some active compounds inter alia saponin, polyphenol, and flavonoid that have antibacterial effects. This study aimed to identify whether the antibacterial effects of mother in law's tongue leaf (Sansevieria Trifasciata) towards the growth of Escherichia coli and Streptococcus sp. This was an experimental laboratory study. The concentrations of mother in law's tongue leaf extract were tested with well methods, as follows: $5 \%, 10 \%, 20 \%$, and $40 \%$. The results showed that this extract at concentration of $5 \%$, $10 \%, 20 \%$, and $40 \%$ could inhibit the growth of $E$. coli with the average diameters of inhibition zones as follows: $7.8 \mathrm{~mm}, 13 \mathrm{~mm}, 14.5 \mathrm{~mm}$, and $17.3 \mathrm{~mm}$ meanwhile of Streptococcus sp. with the average diameters of inhibition zones, as follows: $4.6 \mathrm{~mm}, 9.6 \mathrm{~mm}$, $13 \mathrm{~mm}$, and $15.3 \mathrm{~mm}$. Conclusion: Ethanol extract of mother in law's tongue leaves (Sansevieria Trifasciata) has antibacterial activities against the growth of E. coli and Streptococcus sp. The higher the concentration is, the broader the inhibition zone is.

Keywords: Sansevieriae trifasciata folium, inhibition zone, E. coli, Streptococcus sp.
\end{abstract}

\begin{abstract}
Abstrak: Tanaman Lidah Mertua (Sansevieria Trifasciata) memiliki senyawa aktif yaitu Saponin, Polifenol, dan Flavonoid yang mampu bekerja sebagai antibakteri. Penelitian ini bertujuan untuk mengetahui ada tidaknya daya hambat ekstrak daun lidah mertua (Sansevieria trifasciata) terhadap pertumbuhan bakteri E. coli, dan Streptococcus sp. Jenis penelitian ini eksperimental laboratorik. Kadar ekstrak etanol daun lidah mertua (Sansevieria trifasciata) yang diujikan dengan metode sumuran yaitu 5\%, 10\%, 20\%, dan 40\%. Ekstrak etanol daun lidah mertua (Sansevieria trifasciata) dengan konsentrasi 5\%, 10\%, 20\%, dan 40\% dapat menghambat pertumbuhan bakteri $E$. coli dengan rerata diameter zona hambat masing-masing yaitu 7,8 mm, $13 \mathrm{~mm}, 14,5 \mathrm{~mm}$, dan 17,3 mm sedangkan Streptococcus sp. dengan masingmasing rerata diameter zona hambat yaitu 4,6 mm, 9,6 mm, $13 \mathrm{~mm}$, dan 15,3 mm. Simpulan: Ekstrak etanol daun lidah mertua (Sansevieria trifasciata) mempunyai aktifitas antimikroba terhadap pertumbuhan bakteri E. coli dan Streptococcus sp, dimana makin tinggi konsentrasi ekstrak daun lidah mertua, makin luas zona jernih pada media kultur bakteri E. coli dan Streptococcus sp.
\end{abstract}

Kata kunci: Sansevieriae trifasciata folium, daya hambat, E. coli, Streptococcus sp.

Indonesia merupakan negara yang kaya akan berbagai jenis tumbuhan. Tumbuhan tersebut telah digunakan oleh penduduk Indonesia sejak dahulu di berbagai bidang seperti industri, perkebunan, obat - obatan dan sebagainya. Tumbuhan yang digunakan sebagai obat dikenal dengan nama obat tradisional. Sampai sekarang obat tradisional dan tumbuhan masih banyak digunakan oleh masyarakat karena harga obat tradisional yang biasanya lebih murah dibandingkan dengan obat sintetis, karena 
bahan baku obat - obatan buatan pabrik sangat mahal dan harganya sangat bergantung pada banyak komponen. ${ }^{1}$

Lidah mertua memiliki nama latin Sansevieriae merupakan tanaman yang sudah dikenal lama di Indonesia. Lidah mertua biasanya digunakan sebagai penghias pagar karena warna dominan hijau kuning dan bentuk unik sehingga cocok sebagai elemen taman. ${ }^{2}$ Selain bermanfaat sebagai tanaman hias, serat lidah mertua juga dapat digunakan sebagai bahan baku tekstil yang banyak digunakan di Cina dan New Zealand. ${ }^{3}$ Tanaman lidah mertua juga dipercayai masyarakat memiliki manfaat untuk pengobatan sakit telinga, sakit perut, sakit gigi, luka, ulkus, hemoroid, sebagai antiseptik dan antikanker. $^{2}$

Sejak ditemukan zat antimikroba, banyak zat-zat yang terbukti efektif melawan bakteri, dan mikroba patogen. Namun, perkembangan mikroba patogen dapat membentuk suatu sistem kekebalan / resistensi terhadap satu atau lebih jenis antibiotik. Resistensi antibiotik bisa terjadi melalui 3 mekanisme yaitu obat tidak dapat menyancapai tempat kerjanya, inaktivasi obat dan mikroba mengubah tempat ikatan antibiotik. $^{4}$

Berdasarkan hal diatas, maka sangat masuk akal untuk beranggapan bahwa antibiotik-antibiotik yang baru hanya akan menunda masalah, dan pada saatnya nanti bakteri akan menjadi kebal terhadap antibiotik tersebut. Oleh karena itu para ilmuan medis terutama di Eropa dan Asia memilih penelitian dari antibiotik senyawa tunggal ke antibiotik senyawa kompleks yang berasal dari ekstrak tanaman obat. Hal ini terjadi karena pada ekstrak tanaman obat ditemukan puluhan bahkan ratusan senyawa aktif yang memiliki fungsi yang sama maupun yang berlainan (immunostimulan, antioksidan, bakterisidal, bakteriostatik, sinergisasi antibiotik sintetik, dll) namun dapat bekerja secara harmonis melawan suatu infeksi. ${ }^{5}$

Senyawa aktif pada tanaman obat (khususnya senyawa antimikroba) jauh lebih banyak dan sifatnya jauh lebih kompleks daripada antibiotik sintetik yang memiliki senyawa aktif tunggal (penisilin, makrolide, kuinolon, sefalosporin, dll) sehingga menyebabkan mikroba sulit untuk membentuk sebuah sistem resistensi. Mekanisme kerja tanaman obat masih jauh lebih efektif dibandingkan dengan mengkombinasikan dua atau lebih senyawa tunggal antibiotik sintetik karena ada beberapa jenis mikroba yang dapat resisten terhadap dua atau lebih senyawa tunggal antibiotik sintetik tersebut. ${ }^{5}$

Penelitian ini bertujuan untuk mengukur daya hambat ekstrak daun lidah mertua (Sansevieria trifasciata) terhadap pertumbuhan bakteri Escherichia coli dan Streptococcus sp. yang dikultur pada media agar.

\section{METODE PENELITIAN}

Jenis penelitian ini ialah eksperimental laboratorik. Penelitian dilakukan di Laboratorium Mikrobiologi Farmasi, Fakultas MIPA Universitas Sam Ratulangi dari bulan Oktober sampai Desember 2015. Populasi penelitian ini ialah semua daun lidah mertua (Sansevieria trifasciata). Sampel yang diambil ialah daun lidah mertua (Sansevieria trifasciata) yang di tanam di kebun bunga penulis di kelurahan Kakaskasen 2, Tomohon Utara.

Prinsip penelitian ialah dengan pemberian bakteri $E$. coli dan Streptococcus sp. pada ekstrak etanol daun lidah mertua (Sansevieria Trifasciata) dalam media agar diharapkan dapat terlihat seberapa besar zona hambat yang akan dihasilkan oleh masing-masing dosis ekstrak terhadap pertumbuhan bakteri kemudian dibandingkan dengan kontrol positif ciprofloxacin dan kontrol negatif aquades.

Tahap penelitian ialah pembuatan ekstrak daun lidah mertua, pembuatan kultur dan uji antibakteri terhadap biakan bakteri E. coli dan Streptococcus sp. Larutan kontrol positif dibuat dari tablet ciprofloxacin yang dihaluskan dalam mortar sedangkan kontrol negatif menggunakan aquades steril. Larutan uji ekstrak daun lidah mertua (Sansevieria 
Trifasciata) dengan berbagai konsentrasi (40\%, 20\%, 10\%, 5\%), kontrol positif dan kontrol negatif diteteskan sebanyak $50 \mu \mathrm{l}$ pada sumur yang berbeda, kemudian cawan petri dimasukkan dalam inkubator pada suhu $37^{\circ} \mathrm{C}$ selama 24 jam. Diamati dan diukur diameter zona hambat yang terbentuk dengan menggunakan mistar.

\section{HASIL PENELITIAN}

Hasil pengujian daya hambat ekstrak daun lidah mertua (Sansevieria Trifasciata) terhadap aktivitas pertumbuhan bakteri $E$. coli memiliki nilai positif. Rata-rata diameter zona hambat pada ekstrak 5\%, $10 \%$, 20\% dan $40 \%$ secara berurutan yaitu 7,8 mm, $13 \mathrm{~mm}, 14,5 \mathrm{~mm}$, dan 17,3 mm (Tabel 1).

Hasil pengujian daya hambat ekstrak daun lidah mertua (Sansevieria Trifasciata) terhadap aktivitas pertumbuhan bakteri Streptococcus sp. memiliki nilai positif. Rata-rata diameter zona hambat pada ekstrak 5\%, 10\%, 20\% dan 40\% secara berurutan yaitu 4,6 mm, 9,6 mm, 13,0 mm, dan 15,3 mm (Tabel 2).

Tabel 1. Diameter zona hambat ekstrak daun lidah mertua (Sansevieria Trifasciata) terhadap bakteri E. coli

\begin{tabular}{ccccc}
\hline Bahan Uji & $\begin{array}{c}\text { Petri I } \\
(\mathrm{mm})\end{array}$ & $\begin{array}{c}\text { Petri II } \\
(\mathrm{mm})\end{array}$ & $\begin{array}{c}\text { Petri III } \\
(\mathrm{mm})\end{array}$ & Rata-rata (mm) \\
\hline Aquades & 0,0 & 0,0 & 0,0 & 0,0 \\
Ekstrak 5\% & 8,0 & 7,5 & 8,0 & 7,8 \\
Ekstrak 10\% & 13,0 & 10,5 & 15,5 & 13,0 \\
Ekstrak 20\% & 13,5 & 13,5 & 16,5 & 14,5 \\
Ekstrak 40\% & 19,0 & 15,0 & 18,0 & 17,3 \\
Ciprofloxacin & 31,0 & 26,0 & 25,0 & 27,3 \\
\hline
\end{tabular}

Tabel 2. Diameter zona hambat ekstrak daun lidah mertua terhadap bakteri Streptococcus sp.

\begin{tabular}{ccccc}
\hline Bahan Uji & $\begin{array}{c}\text { Petri I } \\
(\mathrm{mm})\end{array}$ & $\begin{array}{c}\text { Petri II } \\
(\mathrm{mm})\end{array}$ & $\begin{array}{c}\text { Petri III } \\
(\mathrm{mm})\end{array}$ & Rata-rata (mm) \\
\hline Aquades & 0,0 & 0,0 & 0,0 & 0,0 \\
Ekstrak 5\% & 4,5 & 4,0 & 5,5 & 4,6 \\
Ekstrak 10\% & 11,0 & 6.5 & 11,5 & 9,6 \\
Ekstrak 20\% & 12,0 & 14,0 & 13,0 & 13,0 \\
Ekstrak 40\% & 16,5 & 15,5 & 14,0 & 15,3 \\
Ciprofloxacin & 20,5 & 19,0 & 18,5 & 19,3 \\
\hline
\end{tabular}

\section{BAHASAN}

Dalam penelitian ini dibuat ekstrak daun lidah mertua (Sansevieria Trifasciata) dengan larutan etanol yang bersifat ekstraktor polar. ${ }^{6}$ Prinsip dasar penelitian ialah dengan pemberian bakteri E.coli dan Streptococcus sp. pada ekstrak daun lidah mertua (Sansevieria Trifasciata) ke dalam sumur media agar diharapkan dapat terjadi penghambatan pertumbuhan bakteri. Penghambatan pertumbuhan tersebut dapat terlihat dengan adanya zona hambat pada media agar.

Metode ekstraksi yang digunakan adalah metode sumuran karena lebih cocok dan praktis untuk uji herbal atau obat yang berasal dari tanaman. Metode ini membuat ekstrak dapat berdifusi secara maksimal karena bahan akan bertemu langsung dengan media pertumbuhan sampai ke dasar media melalui sumur yang dibuat pada media pertumbuhan kuman.

Penelitian menggunakan dua jenis bakteri yaitu Gram positif Streptococcus 
sp. dan Gram negatif E. coli dimana kedua bakteri tersebut bisa menyebabkan infeksi dan berbagai penyakit pada tubuh manusia. ${ }^{8}$

Pada penelitian ini kontrol negatif yang digunakan ialah aquades sekaligus juga merupakan larutan pengencer kontrol positif maupun ekstrak daun lidah mertua (Sansevieria trifasciata). Ciprofloxacin dipilih sebagai kontrol positif yang merupakan larutan pembanding efek antara obat antimikroba baku dengan larutan ekstrak uji dalam hal ini daun lidah mertua (Sansevieriae trifasciata). Pemilihan ciprofloxacin sebagai kontrol positif karena ciprofloxacin merupakan golongan obat flouroquinolon yang memiliki berfungsi untuk menghambat sintesis DNA bakteri sehingga menghambat resistensi mikroba dan merupakan antimikroba berspektrum luas. $^{8}$

Pengamatan pada bakteri uji E. Coli (Tabel 1) dapat diperhatikan bahwa aquades tidak memiliki daya hambat pertumbuhan bakteri sebagai kontrol negatif dengan tidak ditemukannya zona terang pada sumur yang berisi aquades. Hal ini berbanding terbalik dengan larutan pembanding ciprofloxacin sebagai kontrol positif dimana terlihat memiliki zona hambat yang besar dan sangat mencolok dibandingan dengan empat larutan uji.

Larutan uji ekstrak daun lidah mertua (Sansevieria trifasciata) pada Tabel 1 dengan konsentrasi 5\% sudah menunjukkan adanya penghambatan terhadap pertumbuhan bakteri E. coli. Efek penghambatan makin kuat pada konsentrasi yang lebih besar yaitu pada konsentrasi 10\%, 20\%, dan 40\%. Hal tersebut membuktikan bahwa ekstrak daun lidah mertua (Sansevieriae trifasciata) memiliki efek antimikroba terhadap bakteri E. coli.

Pada Tabel 2, pengamatan pada bakteri uji yang diberikan aquades sebagai kontrol negatif tidak menunjukkan efek antimikroba terhadap pertumbuhan bakteri Streptococcus sp. yang ditunjukkan dengan sumur yang berisi aquades tidak memiliki zona terang. Sebaliknya, larutan pembanding ciprofloxacin sebagai kontrol positif memiliki efek antimikroba yang ditandai dengan adanya zona hambat terhadap pertumbuhan bakteri Streptococcus $s p$.

Larutan uji ekstrak daun lidah mertua (Sansevieria trifasciata) pada konsentrasi 5\% sudah menunjukkan efek antimikroba terhadap bakteri Streptococcus sp. dan efek penghambatan semakin meningkat pada konsentrasi $10 \%$, 20\%, dan 40\%. Hal ini membuktikan bahwa ekstrak daun lidah mertua (Sansevieria trifasciata) memiliki efek antimikroba terhadap bakteri Streptococcus sp.

Pada pengamatan, efek antimikroba makin meningkat pada konsentrasi larutan uji berturut-turut dari 5\%, 10\%, 20, dan 40\% baik pada bakteri E. coli maupun Streptococcus sp. Hal ini menunjukkan adanya hubungan positif kuat antara konsentrasi dan zona hambat yang dihasilkan. Semakin tinggi konsentrasi ekstrak daun lidah mertua maka semakin besar zona hambat yang terjadi. Artinya, larutan ekstrak daun lidah mertua (Sansevieria trifasciata) memiliki efek antimikroba terhadap bakteri $E$. coli dan Streptococcus sp. dengan urutan kekuatan antimikroba pada larutan uji konsentrasi adalah 40\%, 20\%, 10\%, 5\%.

Berdasarkan hasil penelitian, didapatkan bahwa ekstrak daun lidah mertua (Sansevieria trifasciata) memiliki kemampuan antimikroba terhadap bakteri E. coli dan Streptococcus sp. Hal ini disebabkan adanya zat aktif yang terkandung dalam tanaman lidah mertua. Zat aktif yang terkandung dalam ekstrak daun lidah mertua yang kemungkinan dapat menghambat pertumbuhan bakteri yaitu saponin, fenol, dan flavonoid. Saponin merupakan jenis glikosida yang banyak ditemukan dalam tumbuhan. Saponin memiliki karakteristik berupa buih. ${ }^{9}$ Fenol merupakan senyawa dengan gugus -OH yang terikat langsung pada cincin aromatik. Senyawa fenol banyak terdapat di alam dan merupakan intermediet bagi industri untuk berbagai macam produk seperti adhesif dan antiseptik, ${ }^{10}$ sedangkan senyawa flavonoid adalah suatu kelompok senyawa fenol 
terbesar yang ditemukan di alam. ${ }^{11}$ Senyawa-senyawa di atas memiliki efek antiseptik, anti-inflamasi, dan anti kanker. 9-11

\section{SIMPULAN}

Berdasarkan hasil penelitian dapat disimpulkan bahwa ekstrak daun lidah mertua (Sansevieria trifasciata) mempunyai daya hambat terhadap pertumbuhan bakteri $E$. coli dan Streptococcus sp. dengan urutan kekuatan penghambatan dari setiap konsentrasi yaitu $40 \%>20 \%>10 \%>5 \%$.

\section{SARAN}

Perlu dilakukan penelitian lebih lanjut mengenai kandungan zat aktif dari daun lidah mertua (Sansevieriae trifasciata) yang beraktifitas sebagai antimikroba serta mekanisme penghabatannya.

Perlu dilakukan uji aktifitas antimikroba lanjutan terhadap ekstrak etanol daun lidah mertua (Sansevieriae trifasciata) secara in vivo untuk menentukan dosis dan efek toksisitas, serta efek samping dari ekstrak daun lidah mertua (Sansevieriae trifasciata).

\section{DAFTAR PUSTAKA}

1. Salan R. Penelitian faktor-faktor psikososio-kultural dalam pengobatan tradisional pada tiga daerah, Palembang, Semarang, Bali. Jakarta. Badan Penelitian dan Pengembangan Kesehatan, Pusat Penelitian Kanker dan Pengembangan Radiologi, Departemen Kesehatan RI, 2009; p. 40.

2. Sansevieriae, 200 Jenis Spektakuler. Jakarta:
Niaga Swadaya, 2008; p. 2-18.

3. Purwanto A. Sansevieriae Flora Cantik Peyerap Racun. Yogyakarta: Kanisius, 2006; p. 13.

4. H binti Hamzah. 2012. Tingkat Pengetahuan dan Sikap Mahasiswa Universiti Sains Malaysia Kampus Kejuruteraan, Ibong Tebal, Pulau Pinang Tentang Penggunaan Antibiotik Pada Tahun 2011 [Skripsi]. Medan: Fakultas Kedokteran Universitas Sumatera Utara; 2012.

5. Green J. Mengapa Obat-obatan Botanik Menawarkan Janji. In: Terapi Herbal, Pengobatan Alami Mengatasi Bakteri. Jakarta: Prestasi Pustaka, 2005; p. 324.

6. Posangi J. Buku Penuntun Praktikum: Ekstraksi. Manado: Bagian Farmakologi dan Terapi Fakultas Kedokteran Unsrat, 2000; p. 3-4.

7. Gould D, Brooker C. Mikrobiologi Terapan Untuk Perawat. Jakarta: EGC, 2005; p. 69-73.

8. Levinson W. Review of Medical Microbiology. America: The McGraw-Hill Companies, 2008; p. 25-26, 78-79.

9. Prihatman K. Saponin untuk Pembasmi Hama Udang. Bandung: Pusat Penelitian Perkebunan Gambung, 2001.

10. Universitas Atma Jaya Yokyakarta. Lidah Mertua. Available from; http://ejournal.uajy.ac.id/2670/3/2BL01019. pdf, p. 18-19

11. Lenny $\quad$ S. Senyawa Flavonoid, Fenilpropanoida dan Alkaloida [Karya ilmiah]. Medan: Fak. MIPA USU; 2006. 